\title{
ISOLATION AND CHARACTERIZATION OF CARBENDAZIM DEGRADING Trichoderma harzianum RIFAI MUTANTS
}

ITAMAR SOARES DE MELO*

CÉLIA MARIA MAGANHOTTO DE S. SILVA**

JANE L. FAULL***

\begin{abstract}
Mutants of Trichoderma harzianum Rifai, obtained after ultraviolet (UV) light exposure, showed high resistant to the fungicide benomyl. A mutant (2B6) was capable of degrading carbendazim, other fungicide of the benzimidazole fungicide. This mutant degraded $41.5 \%$ of the molecule within five days. This and others mutants (2B1 and 2B2) presented variation in size and frequency of uni-nucleated and/ or bi-nucleated spores compared to the wild type. Four primers generated RAPDs patterns that allowed the mutant to be differentiated from the wild-type. It is concluded that using UV mutagenization, it is feasible to obtain strains of $T$. harzianum with improved pesticide degradation ability.
\end{abstract}

* Agronomist, Ph.D., Empresa Brasileira de Pesquisa Agropecuária (EMBRAPA), Jaguariúna, SP, Brazil (e-mail: itamar@cnpma.embrapa.br).

** Biologist, Ph.D., EMBRAPA, Jaguariúna, SP, Brazil (e-mail: celia@cnpma.embrapa.br).

*** Biologist, Ph.D., Birkbeck College, London University, London, UK (e-mail: j.nicklin@bbk.ac.uk). 


\section{INTRODUCTION}

Trichoderma spp. are common saprophytic fungi and they have been investigated as biological control agents against soil-borne plant pathogens (CHET et al., 1979). Different application approaches have been used including integration of Trichoderma with reduced doses of chemical agents (DEV and DAWANDE, 2010). Trichoderma spp. also have considerable metabolic diversity. For example, Trichoderma spp. are capable of effectively degrading chitin and glucans (ELAD, CHET \& HENIS, 1982), and they seem to be the best source of extracellular-cellulases that can solubilize highly ordered cellulose (RYU \& MANDELS, 1980). The degradation of organic compounds other than cellulose by T. harzianum has also been reported. Katayama \& Matsumura (1993) found a T. harzianum strain capable of degrading DDT, dieldrin, endosulfan, pentachlororonitrobenzene and pentachlorophenol. Recently, a new strain of $T$. viridae associated with Pseudomonas aeroginosa, when applied in treated soil with monochrotophos and methyl parathion, efficiently increased the potential in degrading both pesticides (BALAMUYUGAN et al., 2010). Searching for genetically modified Trichoderma strains with improved abilities will satisfy the growing needs to remediate organophosphate pesticide contaminated soil. TANG et al. (2009) used the REMI (restriction enzymemediated integration) technique to construct transformants of $T$. atroviride with improved capability of degrading organophosphate pesticide dichlorvos. In that work, the authors found 8 transformants that exhibited $30 \%$ higher in degradation rate than the parent isolate. Thus it may be possible to combine biological disease control with pesticide clean up in the rhizosphere.

Some strains of Trichoderma harzianum Rifai are rhizosphere competent (AHMAD \& BAKER, 1987; MELO, FAUL \& GRAEME-COOK, 1997). The rhizosphere maintains specific micro-environments that differ from bulk soil in the availability of nutrients. Therefore it has a higher and more active microbial biomass than the surrounding bulk soil. The rhizosphere may be used as vehicle for inoculation of pesticidetolerant and pesticide degrading microorganisms in situ in combination with biological control ability.

The use of biological systems to bring about the timely remediation of man-made pollutants is the goal of soil bioremediation. Bioremediation utilizes the natural role of microorganisms in transformation, mineralization, or complexation by directing these capabilities toward organic and inorganic environmental pollutants.

The benzimidazole are important fungicides which have been produced on a large scale (DELP, 1995). Benomyl, carbendazim, methyl thiophanate, and thiophanate have been used extensively to control plant pathogenic fungi in several crops.

The aims of this study were to obtain $T$. harzianum mutants resistant to benomyl, to test their ability to increase the degradation rate of carbendazim, and to characterize the mutants morphologically and molecularly via Random Amplified Polymorphic DNA (RAPD).

\section{MATERIAL E METHODS}

\subsection{FUNGUS AND MUTAGENIC TREATMENT}

Trichoderma harzianum, strain TW5, was isolated from soybean rhizosphere soil, and has demonstrated antagonistic ability against Verticillium dahliae (MARTINS-CORDER \& MELO, 1998). Mutants were induced by ultraviolet light irradiation of conidia at a survival level of $5 \%$. The dose was $97.00 \mathrm{uw} \mathrm{cm}^{2} \times 10$. After irradiation, the spores were plated into potato-dextrose-agar (PDA) supplemented with benomyl (500 $\left.\mu \mathrm{g} \cdot \mathrm{mL}^{-1}\right)$. Resistant colonies to benomyl were transferred to test tubes containing Potato Dextrose Agar (PDA) amended with benomyl $\left(100 \mu \mathrm{g} \mathrm{mL}^{-1}\right)$. The stability of resistance was checked by periodically plating colonies in PDA with and without the fungicide.

\subsection{CHEMICALS}

Analytical carbendazim-MBC (methyl benzimidazole-2-ylcarbamate) and benomyl (methyl 1butyl-carbamoyl) benzimidazole-2-ylcarbamate were obtained from E.I. Du Pont. 


\subsection{NUTRIENT SOLUTIONS}

PDA was used for maintenance of fungal cultures. For degradation experiments, various liquid media were previously tested, and PD-50\% (potato $10 \mathrm{~mL}$; dextrose $10 \mathrm{mg}$; distilled water to $1 \mathrm{~L}$ ) was used in these experiments.

\subsection{CHARACTERIZATION OF MUTANTS}

The in vitro activity of benomyl against the mutants was tested on PDA to which aqueous suspensions of the fungicide were added to achieve a series of the required concentrations. All concentrations were based on $50 \%$ active ingredient of the commercial product. The plates were inoculated with a disc of PDA with abundant growth of Trichoderma. Colony diameter was measured in each of three replicates after 10 days of incubation at $28^{\circ} \mathrm{C}$.

The morphology and number of conidia nuclei of selected mutants and the wild-type were determined by incubating the cultures at $28^{\circ} \mathrm{C}$ for 7 days. Once cultures sporulated they were fixed and stained as described by Tanaka, Murata e Kato (1979). Measurement of the conidia was carried out using an ocular micrometer attached to an Olympus-BHS/PM-10 AD microscope, at 10x magnification.

\subsection{CHARACTERIZATION OF MUTANTS WITH RAPD TECHNIQUE}

Mutant 2B6 and the wild-type were characterized using Random Amplified Polymorphic DNA (RAPD). Nucleic acids were extracted as previously described by Raeder \& Broda (1985). DNA was amplified by RAPD technique (WILLIANS et al., 1990). The thermal cycler was programmed for an initial melt for $3 \mathrm{~min}$ at $95^{\circ} \mathrm{C}$, followed by 40 cycles of $1 \mathrm{~min}$ at $94^{\circ} \mathrm{C}$, fast ramp $37^{\circ} \mathrm{C}$ for $1.5 \mathrm{~min}$ and then to $72^{\circ} \mathrm{C}$ for $2 \mathrm{~min}$. A final extension step of $7 \mathrm{~min}$ at $72^{\circ} \mathrm{C}$ was included.

\subsection{LABORATORY STUDIES OF CARBENDAZIM DEGRADATION}

Degradation was studied in cultures containing $100 \mathrm{~mL}$ of medium in $500 \mathrm{~mL}$ Erlenmeyer flasks, enriched with $100 \mu \mathrm{g} \cdot \mathrm{mL}^{-1}$ of MBC. The fungicide was dissolved in $0.5 \%$ acetone aqueous suspension. The Trichoderma strain $2 \mathrm{~B} 6$ was incubated for up to 30 days at $28^{\circ} \mathrm{C}$ in an orbital shaker.

The quantitative determination of the fungitoxic residues, performed from the fifth day, was carried out by High Performance Liquid Chromatography (HPLC), after extraction and purification of the samples. The method was that described by Austin \& Briggs (1976) and modified by Silva (1996). The samples were extracted with ethyl acetate- $\mathrm{HCl} 1 \mathrm{~N}$, concentrated and dispersed again in the mobile phase. After samples filtration, chromatographic analysis was conducted by using a cationic exchange column (Shim pack WCX1 $40 \times 6 \mathrm{~mm}$ ) and the following conditions: column temperature: $40^{\circ} \mathrm{C}$; mobile phase: ammonium phosphate $0.0125 \mathrm{M}$; flood: $0.2 \mathrm{~mL} \cdot \mathrm{min}^{-1}$ and absorbance at $260 \mathrm{~nm}$. Under these conditions, the retention time of MBC was 4 min $30 \mathrm{sec}$. Recovery of MBC from the liquid medium was $70-84 \%$.

Data were subjected to analysis of variance and statistical difference between mean values determined by Tukey's test (GOMES, 1997).

\section{RESULTS AND DISCUSSION}

Three mutants (2B1, 2B2 and 2B6) were resistant to benomyl (Table 1). Benomyl at the concentration of $500 \mu \mathrm{g} \mathrm{mL}^{-1}$ did not reduce spore germination and mutants had good spore production. The mycelial growth was completely normal in solid and liquid media. There was slight reduction in growth rates in the first 4 days of incubation, but after this time the growth was similar to that in culture medium without fungicide. 
TABLE 1 - REDUCTION OF MYCELIAL GROWTH AND SPORULATION OF NEW MUTANTS OF $T$. harzianum RESISTANT TO BENOMYL, IN PDA AMENDED WITH $500 \mu \mathrm{g} \mathrm{mL}^{-1}$ OF THE FUNGICIDE, AND MORPHOLOGICAL CHARACTERISTICS OF THESE MUTANTS AND WILD TYPE

\begin{tabular}{|c|c|c|c|c|c|}
\hline \multicolumn{6}{|c|}{ Reduction of Mycelial Growth (\%) } \\
\hline \multirow[t]{2}{*}{ Strains } & \multicolumn{2}{|c|}{ Days of incubation $^{a}$} & \multirow{2}{*}{$\begin{array}{c}\text { Spore production } \\
\times 10^{8} / \mathrm{mL}^{\mathrm{a}}\end{array}$} & \multicolumn{2}{|c|}{ Size of conidia $(\mu \mathrm{m})^{b}$} \\
\hline & 4 & 10 & & Length $^{c}$ & Width ${ }^{c}$ \\
\hline 2B1 & 21.2 & 7.3 & $6.2 \mathrm{a}$ & $3.1 \pm 0.2$ & $2.7 \pm 0.1$ \\
\hline 2B2 & 8.1 & 0.0 & $6.8 \mathrm{a}$ & $3.2 \pm 0.2$ & $2.7 \pm 0.1$ \\
\hline 2B6 & 10.4 & 0.0 & $8.5 \mathrm{a}$ & $3.6 \pm 0.4$ & $3.3 \pm 0.4$ \\
\hline TW5* & 100.0 & 100.0 & - & $2.9 \pm 0, .1$ & $2.7 \pm 0.1$ \\
\hline
\end{tabular}

${ }^{a}$ Numbers followed by the same letter are not significantly different according to Tukey's test at $\alpha=0,005$.

*The wild-type strain did not grow in medium with benomyl.

b Values are means of 100 replications.

c Values following the signals are standard desviations.

There have been few reports on the effects of benomyl on naturally occurring strains of $T$. harzianum. Pribela, Kovasc e Savillova (1976) reported that benomyl is highly active against T. viride. Baicu (1982) evaluated the high toxicity of benomyl on spore germination and mycelium of T. viride. In this study, the wild-type TW5 was highly sensitive to $1 \mu \mathrm{g} \mathrm{mL}^{-1}$ of benomyl.

Mutants of $T$. harzianum varied in regard to morphology and size and frequency of uni-nucleated and/or bi-nucleated conidia. Mutants had larger conidia than the wild-type and only the mutant 2B6 presented $9 \%$ of spores bi-nucleated. Mutants $2 \mathrm{~B} 1$ and 2B2 produced green colonies that grew rapidly $6-9 \mathrm{~cm}$ in diameter after 7 days at $28^{\circ} \mathrm{C}$ in PDA amended with benomyl. Mutant $2 \mathrm{~B} 6$ produced yellowish colonies that grew slightly slower than 2B1 and 2B2.

Four primers (three of them having 20 bases and one having 10 bases) generated distinct RAPD profile for the mutant and wild-type (Figure 1).

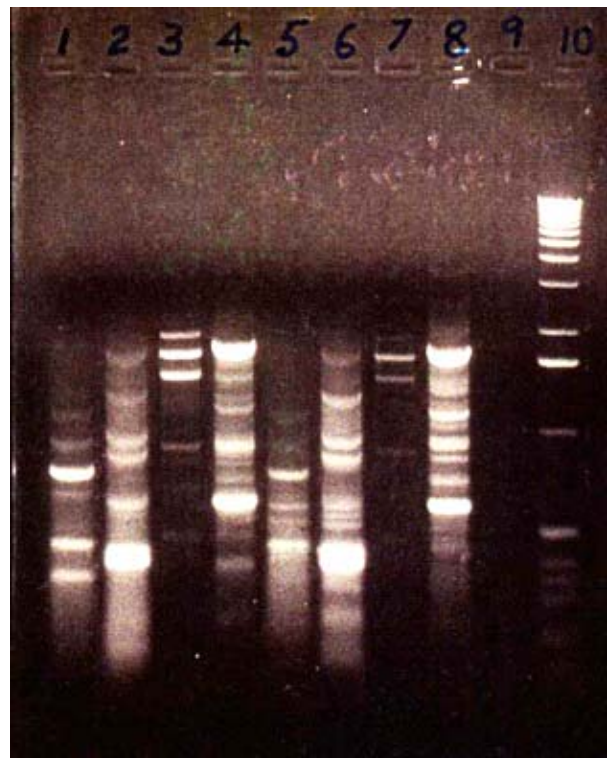

FIGURE 1 - RAPD PROFILE OF THE BENOMYL RESISTANT MUTANT (2B6) AND WILD-TYPE OF T. harzianum GENERATED BY THE PRIMERS P-1 (CGA CTG AAG TGA CCA AGC GC), P-2 (CAC CGC CCC AAA ATG GCC AG), P-3 (TTT GGG GCGG), AND P-6 (GTC CTC AGT CCC CCA ATC CC)

Number on the right indicates sizes (in kilobases) of the components of a 1-kb DNA ladder (Gibco-BRL). Strains numbers are presented above each lane. Numbers 1, 2, 3 and 4 correspond to the primers P-1, P-2, P-3 and P-6, respectively for the strain TW5. Numbers 5, 6, 7 and 8 are the same primers employed for the mutant $2 \mathrm{~B} 6$ and number 9 is the control (without DNA). 
Mutant 2B6, resistant to high concentrations of benomyl, had a high capacity to degrade MBC. In the first five days, this new strain degraded $41.5 \%$ of the product, reaching $66.4 \%$ in 30 days (Figure 2). Carbendazim was degraded with half-life of 37.8 days.

Studies on microbial degradation of benomyl and MBC in soil were carried out by Helweg (1977) who verified that MBC was a poor carbon source and suggested that the biodegradation of MBC is a cometabolic process.

Integration of biological with chemical controls has high potential for success. T. harzianum can be employed with benomyl or MBC at a low dosage to control plant pathogens. Fungicides can increase propagules susceptibility to mycoparasitic attack, and if the antagonist can also degrade the compound there should be a decreased risk of pesticide resistance developing in rhizosphere microorganisms.

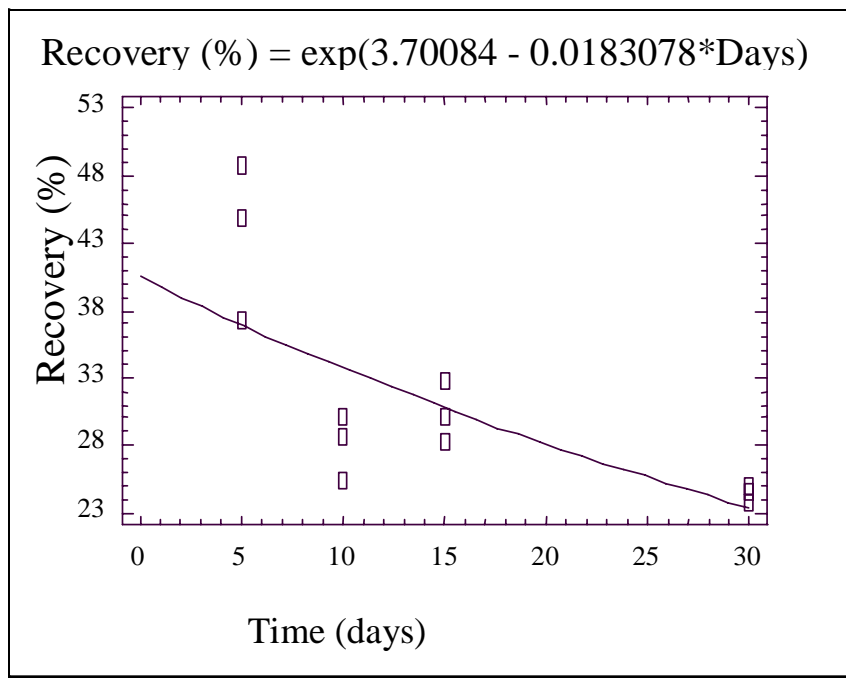

FIGURE 2 - DEGRADATION OF CARBENDAZIM (HALF-LIFE OF THE 37.8 DAYS) BY T. harzianum, MUTANT 2B6, IN LIQUID MEDIUM CONTAINING $100 \mu \mathrm{g} \mathrm{mL}^{-1}$ OF MBC

\section{CONCLUSION}

In this research, it was demonstrated that a new Trichoderma harzianum mutant, obtained by UV irradiation, showed improved abilities of degrading the fungicide carbendazim.

\section{RESUMO}

\section{ISOLAMENTO E CARACTERIZAÇÃO DE MUTANTES DE Trichoderma harzianum ENVOLVIDOS NA DEGRADAÇÃO DE CARBENDAZIM}

Mutantes de Trichoderma harzianum Rifai, resistentes ao fungicida benomil foram obtidos por meio da irradiação com luz ultravioleta. Um mutante (2B6) foi capaz de degradar $41,5 \%$ de carbendazim, outro fungicida do grupo dos benzimidazois. Esse e outros dois mutantes (2B1 e 2B2) apresentaram variação, tanto no tamanho quanto na frequência de conídios uni e binucleados quando comparados com a linhagem parental. Quatro "primers" geraram padrões de RAPD que permitiram diferenciar esses mutantes da linhagem parental. Conclui-se que é possível obter linhagens melhoradas de T. harzianum para degradação de pesticidas, utilizando-se de mutagenização com radiação ultravioleta.

PALAVRAS-CHAVE: DEGRADAÇÃO; FUNGOS; MICRO-ORGANISMOS; BIOTRANSFORMAÇÃO; PESTICIDAS. 


\section{REFERENCES}

1 AHMAD, J. S.; BAKER, R. Rhizosphere competence of Trichoderma harzianum. Phytopathology, v. 77, p. 19821989, 1987.

2 AUSTIN, D.J.; BRIGGS, G.G. A new extraction method for benomyl residues in soil and its application in movement and persistence studies. Pesticide Science, v.7, n.2, p.201-210, 1976.

3 BAICU, T. Toxicity of some pesticides to Trichoderma viride Peers. Crop Protection, v. 1, p. 349-358, 1982.

4 BALAMURUGAN, K.; RAMAKRISHNAN, M.; SENTHILKUMAR, R.; IGNACIMUTHU, S. Biodegradation of methyl parathion and monochrotophos by Pseudomonas aeruginosa and Trichoderma viridae. Asian Journal of Science and Technology, v. 6, p.123-126, 2010.

5 CHET, L.; HADAR, Y.; ELAD, Y.; KATAN, J.; HENIS, Y. Biological control of soil-borne pathogens by Trichoderma harzianum. In: SCHIPPERS, B: GRAMS, W. (eds). Soil-borne plant pathogens. New York: Academic Press, 1979. p. $585-591$.

6 DELP, C.J. Benzimidazole and related fungicides. In: MODERN selective fungicides. Jena: Gustav Fischer Verlag, 1995. p. 291-303.

7 DEV, N.; DAWANDE, A.Y. Biocontrol of soil borne plant pathogen Rhizoctonia solani using Trichoderma spp. and Pseudomonas fluorescens. Asiatic J. Biotech. Res. v.01, p. 39-44, 2010.

8 ELAD, Y.; CHET, L.; HENIS, Y. Degradation of plant pathogenic fungi by Trichoderma harzianum. Canadian Journal of Microbiology, v. 28, p. 719-725, 1982.

9 GOMES, F. P. A estatística moderna na pesquisa agropecuária. 3. ed. Piracicaba: Potafos, 1987, 162 p.

10 HELWEG, A. Degradation and absorption of carbendazim and 2-aminobenzimidazole in soil. Pesticide Science, v. 8 , p. 371-376, 1977 .

11 KATAYAMA, A.; MATSUMURA, F. Degradation of organochlorine pesticides, particularly endosulfan, by Trichoderma harzianum. Environmental Toxicology and Chemistry, v. 12, p. 1059-1065, 1993.

12 MARTINS-CORDER, M.P.; MELO, I.S. Antagonismo in vitro de Trichoderma spp. a Verticillium dahliae. Scientia Agricola, v. 55, p.1-7, 1998.

13 MELO, I.S.; FAULL, J.L.; GRAEME-COOK, K.A. Relationship between in vitro cellulase production of UV-induced mutants of Trichoderma harzianum and their bean rhizosphere competence. Mycological Research, v. 101, p. 1389-1392 1997.

14 PRIBELA, A.; KOVASC, J.; SAVILLOVA, J. Vyler fungicidov proti niekokorym hubam produkcjuclm horks laiki rajcin, jablek a huriek. Ochrana Roslim, v. 12, p. 37-44, 1976.

15 RAEDER, U.; BRODA, P. Rapid preparation of DNA from filamentous fungi. Letters in Applied Microbiology, v. 1, p. $17-20,1985$.

16 RYU, D.D.Y; MANDELS, M. Cellulase: biosynthesis and application. Enzyme and Microbial Technology, v. 2, p. 91$102,1980$.

17 SILVA C.M.M.S. Biodegradação do fungicida carbendazim. 1996. 86 f. Tese (Doutorado em Ciências Biológicas), Departamento de Microbiologia Aplicada, Universidade Estadual Paulista Júlio de Mesquita Filho. Rio Claro, 1996.

18 TANAKA, Y.; MURATA, N; KATO, H. Behaviour of nuclei and chromosome during ascus development in the mating between either rice-strains or weeping lovegrass-strain and strain of Pyricularia. Annals of the Phytopathological Society of Japan, v. 45, p. 182-191, 1979.

19 TANG, J.; LIU L.; HUA, S.; CHEN, Y.; CHEN, J. Improved degradation of organophosphate dichlorvos by Trichoderma atroviride transformants generated by restriction enzyme-mediated integration (REMI). Bioresource Technology, v.100, p. 480-483, 2009.

20 WILLIANS, J.G.K.; KUBELIK, A.R.; LIVAK, K.J.; RAFALSKI, J.A.; TINGEY, S.V. DNA polymorphisms amplified by arbitrary primers are useful as genetic markers. Nucleic Acids Research. v. 18, p. 6531-6535, 1990. 